\author{
ВАСИЛИЙ ИВАНОВИЧ СУПРУН* \\ Волгоградский государственный социально-педагогический \\ университет \\ Волгоград, Россия \\ ЦЗинЛИНь ВАН** \\ Чанчунький университет \\ Чанчунь, Китайская Народная Республика
}

\title{
СЛАВЯНСКИЕ ЯЗЫКИ В СОВРЕМЕННОМ КИТАЕ
}

В статье рассматривается история взаимоотношений славян с китайцами, традиции преподавания славянских языков в Китае, современное состояние славистических исследований и основные вузы, в которых осуществляется преподавание славянских языков как иностранных в современной Китайской Народной Республике.

Ключевые слова: славистика, славяне, Китай, изучение славянских языков, славянская лингводидактика

Из истории дипломатии известно, что впервые контакты славян со Срединной империей произошли в 1618 г., когда группа российских землепроходцев посетила Пекин во время правления династии Мин [11]. Предположения хорватских учёных о том, что Марко Поло, проживший со своим отцом Никколо и дядей Матфео при дворе великого монгольского хана Хубилая, внука Чингисхана, с 1275 по 1291 гг., был хорватом, нуждаются в проверке. Безусловно, какие-то сведения о Китае доходили до славян и ранее, равно как и китайцы что-то могли знать о народах, населявших центральную и восточную Европу. В славянские языки через тюркское и иное посредничество проникают китайские слова. К праславянскому языку восходит слово книі $а$, первоисточником которого послужило древнекитайское слово king [33/2: 262]. Русское слово жемчуг фиксируется в форме жьниугъ в 1161 г. в надписи Ефросинии Полоцкой, встречается оно также в текстах православного писателя епископа Кирилла Туровского (1130 - около 1182); оно восходит к древнетюркскому јӓпс̌ӥ, заимствованному у китайцев [33/2: 46].

*vassuprun@yandex.ru, suprun@vspu.ru

**elizaveta@163.com 
Название самого китайского государства и народа приходят к славянам поздно и разными путями: на востоке в нём отразилось наименование тунгусо-маньчжурской народности киданей, завоевавшая в X в. Китай и основавших там государство Ляо (916-1125) [29]. В тюркских языках этноним приобрёл форму Куtаi и значение 'Китай, китаец', в этом виде он перешёл в русский и другие восточнославянские языки; впервые слово отмечено в Воскресенской летописи под 1534 г. [33/2: 240]. На Западе, в т.ч. у западных и части южных славян, закрепилось другое наименование, заимствованное из индийских языков от восходящего к санскритскому слову Cina-s 'китаец' [42], образованному от наименования династии Цзинь (1115-1234), которую основали чжурчжэни, разгромившие государство Ляо. Так в европейском языковом пространстве встретились два слова, относящиеся к разным историческим периодам китайской истории.

В английском языке топоним China отмечен в 1550 г. [42]. Славяне восприняли его в разных вариантах произношения: польское Chiny получило немецкую инициальную огласовку и использовало древнюю топонимическую плюральную форму, чешское и словацкое С̌ína восходит к итальянскому Cina, сербское, македонское Кина и хорватское Kina, вероятно, обнаруживает связь либо с румынским China, либо с германским Kina, сохранившемся в скандинавских языках. Болгарское Китиай и словенское Kitajska, вероятно, заимствованы у восточных славян.

При династии Цин, пришедшей в 1644 г. на смену династии Мин, продолжились контакты с восточными славянами. Первоначально по традиции, заложенной ещё при династии Юань (1271-1368), языком общения был монгольский. Возможно также, что использовалась латынь, которую завезли в Китай представители ордена иезуитов, в частности Маттео Риччи (1552-1610), который обучил этому языку конфуцианских учёных и вместе с ними переводил на китайский язык труды римских и древнегреческих учёных и писателей, а на латынь - конфуцианских классиков [12; 39; 40; 41].

Однако расширение контактов привело к пониманию, что необходимо изучение русского языка. В 1708 г. император Канси (1654-1722), который вёл войну с Московским государством в Приамурье [21], распорядился создать специальное заведение для подготовки дипломатов, была открыта Школа русского языка при Дворцовой канцелярии (内阁俄 罗斯文官). В ней студенты обучались 5 лет, после чего сдавали письменный экзамен. В 1798 г. было издано первое местное учебное пособие для изучения русского языка. Но уровень обучения в школе был низким. В 1805 г. четыре лучших ученика были направлены в качестве переводчиков на встречу с русскими послами, но не смогли в их речи ничего по- 
нять. Однако были в школе и талантливые ученики, составившие костяк китайской русистики: Юань Чэннин, Мача, Фулахэ, Шу Мин, Умитао и Го Шичунь [17; 18$]$.

При императоре Канси в Китае впервые появилось православие. В ходе военных действий у Албазина (Яксы) в 1686 г. (см. подробнее: [4: 144-154]) было захвачено немало русских пленных, часть из них была размещена в Пекине и Шэнцзине (ныне - Шэньян). В столице русские были были расселены в переулке Хуцзяцюань, их приписали ко «второму жёлтому знамени» восьмизнамённых войск. В их распоряжение был передан храм, посвященный богу преданности и храбрости, богатства и защиты Гуаньгуну, который стал русской Никольской часовней. Позже она была преобразована в храм святой Софии. 30 апреля 1715 г. в Пекин прибыла первая духовная миссия Русской православной церкви во главе с архимандритом Илларионом (Лежайским). После подписания в 1727 г. китайско-российского Кяхтинского договора духовные миссии из России направлялись в Китай периодически. В августе 1732 г. в Пекине была построена Сретенская церковь [38].

Существенный вклад в деятельность Школы русского языка оказал архимандрит Палладий (Пётр Кафаров) (1817-1878), который 30 лет проработал в Пекине в составе Русской духовной миссии [25]. В 1862 г. школа была включена в состав Училища иностранных языков, в котором, помимо русского, преподавались английский и французский. Начали осуществляться переводы русских писателей на китайский язык: первыми перевели басни И.А. Крылова, в 1903 г. отдельной книгой вышла «Капитанская дочка» А.С. Пушкина.

С конца 1890-х годов, когда началось строительство Китайской Восточной железной дороги (КВЖД), были построены церкви, учреждены епархии в Харбине, Шанхае, Тяньцзине, Циндао, Гуанчжоу, Синьцзяне. В Китае получает распространение церковнославянский язык, на котором ведётся богослужение.

После Октябрьской революции и Гражданской войны в России, в которой на стороне большевиков приняло участие большое число китайцев, началось обучение китайских студентов в советских вузах. Первая группа прибыла в Москву в 1920 г.

Определённое влияние на распространение русской культуры в Китае оказали эмигранты, не принявшие революцию и покинувшие родину. Крупным центром русского влияния был Харбин, где ещё в конце XIX в. появилась большая колония выходцев из России, строивших КВЖД и занятых её эксплуатацией. К началу Первой мировой войны русские составляли в Харбине 64,5 \% от общего числа жителей [7: 162]. Любопытно, что, поселившись в Китае, русские не только осваивали местные названия, но и принесли с собой топонимы для обозначения 
созданных ими поселений и их частей. Так, Харбин разделялся русскими на Пристань, Новый город и Сунгарийский городок, который обычно именовался Нахаловкой [27: 24]. Подобное наименование встречается во многих российских городах: так обозначается часть поселения, в которой жители самовольно заняли под постройки землю (до сих пор в Волгограде часть города именуется в народе Нахаловка). Как правило, в Нахаловках проживали бедные горожане в склоченных из подсобного материала жилищах. Такой была Нахаловка и в Харбине.

После революции сюда устремились русские люди преимущественно из Сибири и Дальнего Востока, появился «русский Харбин». К 1920 г. население города составляло 200 тысяч человек, из них свыше 50 тысяч были русскими людьми (точнее, россиянами, поскольку в это число включались украинцы, евреи, татары и другие выходцы из России), в 1931 г. численность населения возросла до 332 тысяч человек, 64 тысячи были европейцами (в основном русскими) и 5 тысяч - японцами и корейцами [27: 24]. Харбин был своеобразным Вавилоном - «международной выставкой рода человеческого» [7: 64]. До 1926 г. в Харбине было русское городское самоуправление, что также требовало использования русского языка как официального [26: 8; 24].

В городе развивалась культурная и литературная жизнь на русском языке. Группа молодых поэтов создала объединение «Молодая Чураевка», названное по роману-эпопее «Чураевы» писателя-эмигранта Георгия Дмитриевича Гребенщикова (1884-1964), «Бояна Сибири» [15]. В Харбине с 1932 года выходила литературная газета «Чураевка» (первоначально «Молодая Чураевка» как еженедельное приложение к газете «Harbin Daily News»), в которой публиковались русские и русскоязычные авторы. Но она просуществовала всего два года, поскольку в начале 1930-х гг. Япония захватила Северо-Восточный Китай, многие русские харбинцы перебрались в Шанхай.

Новым местом расцвета русской эмигрантской литературы стал этот город. Здесь было создано общество «Шанхайская Чураевка», которое впоследствии вошло в объединение «Восток». Крупным литературно-художественным объединением в предвоенные годы было содружество «ХЛАМ», названное не без намёка на эпатаж, но расшифровавшееся как «художники, литераторы, артисты, музыканты» [32].

В 1936 г. русский литератор и издатель Владимир Данилович Жиганов (1896-1978) напечатал в Шанхае альбом «Русские в Шанхае», во вступлении к которому писал: «Поработившей меня идеей стала идея увековечить русских людей, которые, уйдя от интернациональной власти за границу, честно жили, трудились и прославляли русское имя. Так решил потому, что в России были в то время люди, которые утверждали, что русские эмигранты есть отбросы России, что они есть сор, выметен- 
ный из нашей страны советской властью. Умолчать и не сказать правды я не мог» [14]. После завершения гражданской войны в Китае и создания Китайской Народной Республики (1949) бо́льшая часть русских и русскоязычных шанхайцев перебралась в другие страны, кто-то вернулся в СССР, в результате русская эмигрантская литература Шанхая прекратила существование. Следует, однако, подчеркнуть, что эти литературные группы жили собственной творческой жизнью, мало соприкасались в своём творчестве с китайцами, практически не оказали влияния на распространение русского языка в Китае.

В 1949 году в Пекине был основан Университет русского языка (ныне Пекинский университет иностранных языков). В 1950 г. русский язык как специальность преподавался в 19 вузах КНР. Русский язык обязательной дисциплины в средней и высшей школе. Появились талантливые учёные-русисты (Лю Цзэжун), переводчики (Цюй Цюбо, Ба Цзинь, Мао Дунь, Лу Синь и др.).

Во времена «культурной революции» (1966-1976) изучение иностранных языков подвергалось критике, русская литература изымалась из библиотек. Только в 1978 г. снова началось преподавания русского языка и студенческий обмен, но к этому времени ведущее место в системе образования Китая стал занимать английский язык.

В 1992 между Россией и Китаем было подписано соглашение о культурном сотрудничестве, предполагавшее расширение изучения языков в обеих странах. Его идеи были продолжены в новых договорах: О добрососедстве, дружбе и сотрудничестве» (2001) и «Об изучении русского языка в Китайской Народной Республике и китайского языка в Российской Федерации» (2005). Ныне в Китае работают 65 вузов, где ежегодно подготавливают около 7000 специалистов, владеющих русским. Кроме того, в 300 университетах для 30 тысяч учащихся русский преподают как иностранный. Около 15 тысяч студентов выезжают на постоянную и временную учёбу в Россию $[9 ; 37 ; 36 ; 6]$.

Наиболее крупными центрами научно-исследовательской и дидактико-методической работы в области русистики являются Пекинский университет, Далянский университет иностранных языков, Хэйлудзянский университет, Шанхайский и Пекинский университеты иностранных языков. Набирают силы Тяньцзиньский университет иностранных языков и Чанчунький университет, в которых работают опытные китайские специалисты высшей квалификации, получившие образование и защитившие диссертации по русистике в России, и российские преподаватели.

Русский язык преподаётся как обязательный предмет более чем в ста школах, общее число учащихся приближается к 90 тысячам. Однако русский язык распространён в различных регионах Китая неравномерно. Прежде всего, его преподавание сосредоточено в столице и в круп- 
ных городах, а также в приграничных провинциях. Согласно опросу, проведённому в 2013 году среди китайских студентов в северных районах Китая (Маньчжурия, Цицикар, Яньтай, Тяньцзинь и Хайлар), 74\% из них хотели бы выучить русский язык. В приграничном городе Суйфэньхэ русский язык преподаётся во всех учебных заведениях. В юго-восточном Китае спрос на русский язык значительно ниже, в университетах обучается на русском отделении не более 15-20 человек.

Традиционно большой интерес к русскому языку наблюдается в Синьцзян-Уйгурском автономном районе, где он преподаётся в 20 университетах, училищах и школах, число изучающих превысило 3 тысячи человек. В городе Инине имеется русская школа. Директор этой школы Николай Иванович Лунёв (卢尼奥夫 - 尼古拉 - 伊万诺维奇) - гражданин Китая, русский по национальности, депутат Народного консультативного совета КНР. Его дед с семьёй в 1932 г. прибыл в Китай, спасаясь от голода и коллективизации. Он поселился в Кульдже, где образовалась многочисленная русская диаспора. Николай Иванович на заседаниях парламента представляет всю русскую общину КНР.

Н.И. Лунёв прекрасно владеет русским языком, судя по его интервью российским масс-медиа, речь отличается чистотой и правильностью. Однако в целом в русской диаспоре Китая как этнические русские, так и в особенности дети смешанных браков постепенно утрачивают русский язык. Как отмечает Н.Д. Голев, происходит «утрата непосредственного общения с носителями родного языка в комфортной культурно-духовной атмосфере. Её отсутствие - решающий фактор энтропийных тенденций материнского языка» [8: 64]. Пять языковых личностей русскоязычных граждан КНР описаны в диссертации С.В. Гордеевой [10].

Этнические русские в Китае (俄罗斯族) представляют один из 56 малых этносов, официально признаваемых государством. Помимо Синьцзян-Уйгурского автономного района, где они живут в основном в городах Инине (Кульдже), Тачэне (Чугучаке) и Урумчи, русские компактно отмечены на севере провинции Хэйлудзян и в городском уезда Аргунь-Аци автономного ра йона Внутренняя Монголия. В так называемом Трехречье - долине рек Ган, Дербул и Хаул на западе Маньчжурии и на правой берегу Амура в провинции Хэйлунцзян с 20-30-е гг. XX в. до настоящего времени функционировал русский язык [24: 92]. В автономном районе Внутренняя Монголия с 2008 г. работает Русский этнографический музей, в котором имеется несколько сотен экспонатов: национальная одежда, домашняя утварь и даже настоящие дома. В стране действуют несколько русистских общественных организаций: Пушкинское общество, Ассоциация изучения русской и советской литературы, Ассоциация преподавателей русского языка и литературы [16]. 
Украинцы были в составе посольств, торговых и духовных миссий, прибывавших из России, они не выделялись среди остальных участников, общались на русском языке. С 1908 по 1911 г. чрезвычайным и полномочным министром в Пекине (позже посланником при империи Цин) был полтавский дворянин Иван Яковлевич Коростовец (1962-1933), автор трудов о Китае и Монголии [3]. В конце XIX в. многие украинцы прибыли в Маньчжурию на строительство КВЖД, часть из них прибыла из так называемого Зелёного клина, дальневосточной территории, куда устремилось в конце XIX - начале XX в. значительное число украинцев (до $60-70 \%$ от всех переселенцев) [20]. В шутку, а порой и всерьёз Зелёный клин именовали Закитайщиной.

В 1907 г. в Харбине был создан Украинский клуб, занявшийся просветительской деятельностью. Его основателем был В.С. Опадчий, который участвовал и в строительстве Свято-Покровской церкви в Харбине. Она с 1920 г. располагалась в Украинском доме, а в 1930 г. была перенесена в специально построенное для неё здание [35: 244; 24]. Эта церковь до сих пор является действующим православным храмом Харбина. В 1917-1921 гг. были открыты начальная украинская школа, 1-я украинская смешанная гимназия и двухклассное высшее начальное училище [24], был построен Украинский дом на улице Новоторговой. В нём находились клуб, библиотека, большой зал со сценой, где проводились также концерты украинского хора, спектакли и слушались оперы украинских авторов. При клубе работал кружок по изучению украинского языка [35: 282-283; 24]. Официальным органом украинской национальной колонии был журнал «Вестник», выходила и украинская националистическая газета «Зов Украины» [35: 283]. В сентябре-декабре 1925 году выходил еженедельник «Украинская жизнь». В 1923 г. украинские организации в Маньчжурии были ликвидирован, позже конфисковали дом и имущество Украинского клуба, но, по другим данным, ещё и в 1940-е гг. в городе действовало украинское национальное общество. После 1949 г. большинство украинцев выехало из Китая на Тайвань и Филиппины, а оттуда разъехалось в Австралию, Аргентину, Канаду и США.

В 1912 году в газете «Минсинь жибао» писатель Чжоу Цзожень рассказал о жизни и творчестве Тараса Григорьевича Шевченко, в 1934 году в Китае впервые были опубликованы в переводе его произведения. Позже на китайский язык переводились Иван Франко, Леся Украинка и другие украинские писатели. В 1960-е гг. в Уханьском университете был открыт Центр изучения Украины. В период ухудшения советско-китайских отношений в конце 1960-х - середине 1980-х гг. в Китае были переведены и опубликованы труды украинских антисоветчиков, в 1979 г. были радушно приняты учёные из западной украинской диаспоры профессор Карлтонского университета в Оттаве (Канада) Богдан Боцюркив, 
журналист и политик, преподаватель Украинского свободного университета в Мюнхене Борис Левицкий (1915-1984) и бывший воин Украинской повстанческой армии Петро Потичный.

В 1999 г. Институтом лексикографии Хэйлунцзянского университета в Харбине был издан украинско-китайский словарь объёмом в 21 тысячу слов [34]. Планируется издание китайско-украинского учебного словаря, грамматики украинского языка, самоучителя украинского языка для китайцев, книги о выдающихся деятелях украинской культуры. В Пекине, Шанхае, Гуанчжоу, Харбине и Гонконге созданы добровольные объединения украинцев, проживающих в этих городах, нацеленные на решение текущих проблем и на удовлетворение национально-патриотических нужд украинской диаспоры, которая насчитывает около 20 тысяч человек. В апреле 2014 года создана Ассоциация украинских студентов и выпускников китайских университетов, которая также решает вопросы пропаганды украинской культуры в Китае.

В конце 1920-х гг. в Харбин из Польши для руководства Русской католической епархией византийско-славянского обряда (униаты) в Маньчжурии был направлен архимандрит Фабиан Абрантович, неугодный польскому католическому духовенству, поскольку он подчёркнуто говорил на белорусском языке, «вызывая этим постоянное раздражение церковных и светских властей Польши, и в итоге был направлен 'на працу між чужымі ў Маньчжурыю'» $2: 133 ; 24]$. Были здесь и другие священники-белорусы с такой же судьбой. Вероятно, на севере Китая звучала белорусская речь, однако каких-либо очагов образования и культурной деятельности не зафиксировано.

Уже в наши дни постепенно расширяются связи китайских лингвистов и переводчиков с белорусами. Белорусский язык изучается во Втором Пекинском университете иностранных языков. Будет осуществлён первый набор на специальность «белорусский язык» в Тяньцзиньском университете иностранных языков, в котором при участии учёных из Белорусского государственного университета, Белорусского государственного педагогического университета, Минского государственного лингвистического университета и Белорусского национального технического университета была проведена международная конференция 'Китайско-белорусское сотрудничество в сфере высшего образования в рамках концепции 'Один пояс - один путь'», прошёл также фестиваль культур.

В феврале 2015 г. в Минске проводилась международная книжная выставка-ярмарка. Ранее в белорусских литературно-художественных журналах время от времени появлялись публикации произведений китайских поэтов-классиков в переводе на белорусский и русский языки. Издательским домом «Звязда» была издана авторская антология переводов лауреата Государственной премии Республики Беларусь Миколы 
Метлицкого «Под крыльями Дракона. Сто поэтов Китая». Накануне выставки появилась в свет новая книжная серия «Светлые знаки. Поэты Китая». В первых книгах вышли переводы произведений Ван Вэя, Ду Фу, Ли Бо, Ай Цина. Переводы осуществили Рыгор Бородулин, Наум Гальперович, Леонид Дранько-Майсюк, Татьяна Сивец, Рагнед Малаховский.

К 1920-м гг. польская диаспора в Харбине составляла от 2,5 до 5 тысяч человек [1: 44]. Правда, эта цифра сильно расходится с официальными данными за 1910 г., когда здесь было обнаружено только 53 поляка [7: 63], возможно, в предыдущие данные включены прибывшие с территории Царства Польского евреи, украинцы и белорусы. Здесь звучала польская речь, было основано землячество, переросшее в общество «Господа Польска», которое организовывало празднование национальных праздников, благотворительные вечер и пр. [35: 192-193; 24]. В Харбине существовало три польских национальных учебных заведения: гимназия им. Г. Сенкевича, школа В.Ф. Лазовского, польское высшее начальное училище [2: 129; 24], польские приходские школы при костелах св. Станислава и св. Иосафата [7: 64]. Издавались еженедельник «Тыгодник Польски» с приложением «Далеки Всхуд» [30: 468; 2: 129; 24], газета «Ojczyzna» [35: 193].

В 1910 г. в Харбине проживало 33 чеха [7: 63]. В их семьях, несомненно, звучала родная речь.

Одним из первых сербов, побывавших в Китае, был Сава Лукич Владиславич-Рагузинский (1669-1738). С начала 1708 г. он навсегда поселился в России, стал сподвижником Петра I. В октябре 1725 г. после кончины императора-реформатора Сава Рагузинский был направлен в Китай для извещения китайского императора о смерти Петра I и восшествии на российский престол Екатерины I, но на самом деле у него была более масштабная задача урегулирования торговых отношений и пограничных вопросов между Россией и Китаем. Как отмечают исследователи, его дипломатическая деятельность в Китае была сродни подвигу [31]. Русско-китайские переговоры в Пекине тянулись полгода, они были изнурительными. Состоялось 48 конференций с китайской стороной, на которых в жарких спорах обсуждалось 20 проектов. С.Л. Рагузинский твёрдо отстаивал интересы России. Он смело заявил на переговорах: «Российская империя дружбы богдыхана желает, но и недружбы не очень боится, будучи готова к тому и другому». В 1727 г. переговоры продолжились на границе. Договор между Россией и Китаем был подписан в Нерчинске, 21 октября 1727 г. он был ратифицирован в Кяхте. Граница между Россией и Китаем в районе Монголии была установлена в соответствии с принципом uti possidetis (каждый владеет тем, чем владеет теперь). Кяхтинский договор стал важной вехой в истории отношений России и Китая. Вплоть до середины XIX в. он служил их 
юридической основой. Главная роль в заключении Кяхтинского договора принадлежала Рагузинскому, который в стесненных обстоятельствах защищал и отстаивал интересы России. За заслуги на дипломатическом поприще он получил чин тайного советника и был пожалован орденом Александра Невского [31].

В 1727 г. С.Л. Рагузинский заложил город Кяхту, который вплоть до второй половины XIX в. был главным пунктом торговли между Россией и Китаем и где впоследствии сложился своеобразный русско-китайский торговый пиджин [22; 13].

Отмечены в 1910 г. в Харбине и болгары [7: 63 24], видимо, это были единичные представители южнославянского народа, которые участвовали в строительстве и эксплуатации КВЖД.

В настоящее время осуществляется сотрудничество в области образования и культуры между Хорватией и КНР, в марте 1993 г. подписано соглашения о культурном сотрудничестве. С октября 2004 г. в Университете Загреба можно получить степень магистра синологии, а в Пекинском университете иностранных языков - магистра хорватского языка. В соответствии с план сотрудничества в области образования предоставляются ежегодные стипендии для студентов из КНР и Хорватии.

О преподавании словенского языка пока ничего неизвестно, имеются лишь политические и экономические контакты между государствами. С визитами в Китай прибывали словенские премьер-министры Антон Роп, Янез Янша, Мирослав Церар. В Любляне проводился словенско-китайский бизнес-форум, но вопросы преподавания словенского языка в Китае на нём не рассматривались.

В Чанчунском университете планируется начать преподавание славянских языков как вторых в дополнение к русскому. Первоначально предполагается открыть программы по польскому, чешскому и сербскому языкам, впоследствии возможно включение в обучение других славянских языков.

Китайская славистика в настоящее время на подъёме: сложились коллективы учёных-исследователей и педагогов-практиков, которые уверенно реализуют современные подходы к научно-исследовательской и лингводидактической деятельности в области славяноведения.

\section{ЛИТЕРАТУРА}

Аблажей Н.Н. С востока на восток: Российская эмиграиия в Китае / Отв. ред. В.А. Ламин. Новосибирск: Изд-во СО РАН, 2007. 300 с.

Аблова Н.Е. КВЖД и российская эмиграиия в Китае: Межяунарояные и политические аспекты истории (первая половина XX в.). М.: Русская панорама, 2004. 432 c. 
Абрикосов Д.И. Суgьба русского gипломата. М.: Русский путь, 2008. 534 с.

Александров В.А. Россия на gальневосточных рубежах (вторая половина XVII в.). Хабаровск. 1984. С. 144-154.

Белорусско-китайский культурный и образовательный диалог: история, современное состояние, перспективы: сборник научных статей / под научн. ред. Н.Н. Хмельницкого. Минск: РИВШ, 2017. 157 с.

Бутенко Л. И., Пань Х. Русский язык и русская литература в образовательном пространстве Китая // Лосевские чтения: Труды междунар. ежегод. науч. конф. Новочеркасск: Юж.-Рос. гос. политех. ун-т (НПИ) им. М.И. Платова, 2015. С. 214-220.

Василенко Н.А. О численном и национальном составе населения Харбина в 1898-1917 гг. // Дальний Восток - Северо-Восток Китая: исторический опыт взаимодействия и перспективы сотрудничества: матер/ междунар. науч.-практ. конф. Хабаровск: Частная коллекция, 1998. С. 62-64.

Голев Н.Д. Лингвоперсонологическое измерение речи русских переселениев в зарубежье (метоgологические заметки) // Вестник Кемеровского государственного университета. 2015, № 4(64), т. 4. С. 60-65.

Голик М. Я Русский язык в Китае: прошлое и настоящее // Филологические науки. Вопросы теории и практики (Тамбов). 2016. № 1-2 (55). С. 108-110.

Гордеева С.В. Русский язык в приграничном Китае: на матер. речи русских переселенцев в Китай 20-40-х гг. ХХ в. и их потомков: Автореф. дис. <..> канд. филол. наук. Томск, 2015. 26 с.

Дацышен В.Г. История русско-китайских отношений (1618-1917 гг.): Учебное пособие. Благовещенск: Изд-во БГПУ, 2005. 260 с.

Дубровская Д.В. Миссия иезуитов в Китае. Маттео Риччи и другие (1552-1775 гг.). М.: Крафт+; Институт Востоковедения РАН, 2001.

Жданова Н.А. Русско-китайский пиджин Забайкалья среди других форм современных контактных языков // Вестник Бурятского государственного университета. 2014. № 10, С. 84-88.

Жиганов В.Д. Русские в Шанхае: Альбом. Шанхай: Изд-е В.Жиганова, тип. изд-ва «Слово», 1936.

Казак В. Лексикон русской литературы XX века = Lexikon der russischen Literatur ab 1917 / [пер. с нем.]. М.: РИК «Культура», 1996. XVIII + 491 с.

Курто О. И. Русский мир в Китае: исторический и культурный опыт взаимодействия русских и китайцев. М.: Наука; Вост. лит., 2013. 374 с.

Лапин П.А. Школа русского языка при Дворцовой канцелярии в Цинском Китае (начало XVII - вторая половина XIX в.) // Вестник Московского университета. Серия 13: Востоковедение. 2009а. № 3. С. 103-126.

Лапин П. А. Первая школа русского языка в Китае. М. Вост. лит., 2009б. 125 с.

Ларичев В. Е. Путешествие в страну восточных иноземиев. М., 1983.

Мелихов Г.В. Маньчжуры на Северо-Востоке (ХVII в.). М., 1974.

Меньшиков А.А. Материалы по обслеgованию крестьянских хозяйств Приморской области. Саратов, 1912.

Непомнин О.Е. История Китая: эпоха Цин. XVII - начало ХХ века. М.: Вост. лит., 2005. 712 с. 
Оглезнева Е.А. Русско-китайский пияжин: опыт соииолингвистического описания. Благовещенск, 2007.

Оглезнева Е.А. Славянское языковое присутствие в Китае первой половины XX в. (на материале Харбина - центра русского восточного зарубежья) // Pyсин. 2016. № 3(45). С. 90-106.

П.И. Кафаров и его вклаg в отеиественное востоковеgение: Матер. конф. / Под ред. А.Н. Хохлова. В 3 ч. М.: Наука, 1979.

Райан Н.В. Россия - Харбин - Австралия: сохранение и утрата языка на примере русской диаспоры, прожившей XX век вне России. М.: Русский путь, 2005. 208 c.

Русские в Китае / Под общ. ред. и предисл. А.А. Хисамутдинова; А.А. Хисамутдинов, Л.П. Черникова, Т.Н. Калиберова, Д.А. Поздняев, М.В. Дроздов и др. Шанхай: Изд. Координац. совета соотечественников в Китае и Русского клуба в Шанхае, 2010. 572 с.

Росов В.А. Белый Храм на высоких горах. Очерки о русской эмиграиии и сибирском писателе Георгии Гребенщикове. СПб.: Алетейя, 2004. 120 с.

Россия и Китай: четыре века взаимодействия. История, современное состояние и перспективы развития российско-китайских отношений Лукин А.В. (ред.) М.: «Весь Мир», 2013. 704 с.

Сапелкин А.А. Из истории польской колонии Харбина (1896-1932) // Россия и Китай на дальневосточных рубежах. 3. Благовещенск: Амур. гос. ун-т, 2002. С. 464-469.

Славянские нароgы Юго-Восточной Европы и Россия в XVIII в. / Отв. ред. И.И Лещиловская. М.: Наука, 2003. 315 с.

Солодкая М.Б. Издательская деятельность русской эмиграции в Китае: Харбин, Шанхай: 1917-1947. Автореф. дис. <...> канд. ист. наук Краснодар, 2006. 22 c.

Фасмер М. Этимологический словарь русского языка. В 4 т. 2-е изд. М.: Прогресс, 1986-1987.

Чжен Шупу. Украйнсько-китайський словник. Пекин: Шанъу иньшугуань, 1999. $589 \mathrm{c.}$

Хисамутдинов А.А. Российская эмиграиия в Китае: опыт энииклопеgии. Владивосток: Изд-во Дальневост. гос. ун-та, 2002. 360 с.

Цзюй Дунвэй. Обучение русскому языку в Китайской Народной Республике // Традиции семейного чтения - основа литературного образования: матер. IV Байкальских всерос. с межяунар. уиастием роgит. итений. Иркутск: Аспринт, 2015. С. 41.

Чжан Синьсинь, Чжан Юйсинь. Изучение русского языка в Китае как проблема межкультурного общения // Образование, наука, культура в современном мире: матер. Междунар. науч. веб-кконф. «Базовые идеи ЮНЕСКО в современном образовании, культуре и науке». М.: Пашков дом, 2014. С. $176-182$.

Чжан Хайбинь // http://russian.china.org.cn/russian/80135.htm

Cronin V. The Wise Man from the West: Matteo Ricci and his Mission to China. London: Harvill Press, 2000. 
Dreyfus P. Mattèo Ricci: le jésuite qui voulait convertir la Chine. Paris: Éd. du JubiléAsie, 2004.

Fontana M. Matteo Ricci. Un gesuita alla corte dei Ming. Milano: Mondadori, 2005.

Harper D. Online Etymology Dictionary // http://www.etymonline.com/abbr. php?allowed_in_frame $=0$

Vasiliy Ivanovich Suprun

Jinglin Wang

\section{SLAVIC LANGUAGES IN MODERN CHINA}

\section{Summary}

The article discusses the history of the relationship between the Slavs and the Chinese, traditions of teaching Slavic languages in China, the current state of Slavic studies and key universities which is teaching Slavic languages as foreign language in modern People's Republic of China.

Key words: Slavic studies, Slavs, China, the study of Slavic languages, Slavic language didactics 